ROCZNIKI TEOLOGICZNE

Tom LXVII, zeszyt 7 - 2020

DOI: https://dx.doi.org/10.18290/rt20677-6

\title{
KALINA WOJCIECHOWSKA
}

\author{
„ŁASKĄ... PRZEZ WIARĘ” \\ - LUTRA KONCEPCJA USPRAWIEDLIWIENIA GRZESZNIKA \\ PERSPEKTYWA EGZEGETYCZNO-HERMENEUTYCZNA
}

\author{
"BY GRACE ... TROUGH FAITH" \\ — THE LUTHER'S CONCEPT OF JUSTIFICATION OF A SINNER: \\ EXEGETICAL AND HERMENEUTICAL PERSPECTIVE
}

\begin{abstract}
A bstract. The article analyzes the issue of justification trough faith on the basis of the Joint Declaration on the Doctrine of Justification and two commentaries by Martin Luther - Lectures on Romans (1516) and Commentary on the Epistle to the Galatians (1535). The discussed aspects of justification are mentioned in the Joint Declaration in point 11: justification as forgiveness of sins (cf. Rom 3:23-25); as liberation from the dominating power of sin and death (Rom 5:12-21); as liberation from the curse of the law (Gal 3:10-14); as acceptance into communion with God: already now, but then fully in God's coming kingdom (Rom 5:1f); and as unity with Christ and with his death and resurrection (Rom 6:5). Each of these aspects ends with a summary showing the similarities and differences between Luther's approach to justification and the interpretation of the doctrine of justification in the Joint Declaration.
\end{abstract}

Key words: justification; faith; law; Gospel; grace; Martin Luther; Commentary on the Epistle to the Galatians; Lecture of the Epistle to the Romans; Joint Declaration on the Doctrine of Justification.

Marcin Luter nie napisał komentarza do Listu do Efezjan $(2,8)$, z którego pochodzi tytułowy cytat. Reformator nie odniósł się też do Ef 2,8 w kazaniach, choć kazania na teksty z Listu do Efezjan głosił. Rekonstrukcję zatem podejścia reformatora do usprawiedliwienia na bazie egzegezy i hermene-

Dr hab. KAlina WoJciechowsKA, prof. ChAT - Chrześcijańska Akademia Teologiczna w Warszawie, Katedra Nowego Testamentu i Języka Greckiego, ewangelicka biblistka, wykładowczyni także w Ewangelikalnej Wyższej Szkole Teologicznej oraz na wydziale Artes Liberales UW; adres do korespondencji - e-mail: kalinawojciechowska@icloud.com; ORCID: https://orcid.org/ 0000-0001-8639-2727. 
utyki należy oprzeć na innych tekstach. Tu oczywiście pojawia się pytanie, na jakich, ponieważ zwłaszcza po roku 1518/1520, a więc po tzw. przełomie reformacyjnym, temat usprawiedliwienia był jednym $\mathrm{z}$ dominujących $\mathrm{w}$ pismach egzegetycznych Lutra.

\section{PODSTAWA ŹRÓDŁOWA I STRUKTURA ARTYKUŁU}

Z pomocą w wyborze przychodzi Wspólna Deklaracja $w$ sprawie nauki o usprawiedliwieniu (WD) ${ }^{1}$, która w punktach 9-12 podaje w skondensowany, encyklopedyczny sposób rozumienie pojęć „sprawiedliwość” i „usprawiedliwienie” w różnych kontekstach biblijnych ${ }^{2}$. „Wśród tych określeń wyróżnia się «usprawiedliwienie» grzesznika przez Bożą łaskę, które dokonuje się we wierze; było ono podkreślane szczególnie w okresie Reformacji” (WD punkt 9). Dzięki wykazowi sigli nietrudno zauważyć, że najwięcej odniesień do usprawiedliwienia znajduje się w Liście do Rzymian i w Liście do Galatów, a zatem Lutrowe komentarze do tych pism będą stanowić podstawowe źródło materiałowe, natomiast za bazę organizującą cały artykuł posłużą punkty „Biblijnego orędzia o usprawiedliwieniu” we Wspólnej Deklaracji, W szczególności zaś punkt 11.

Punkt 10 WD wymienia elementy, które składają się na paulińską naukę o usprawiedliwieniu, i charakteryzuje je na podstawie wybranych passusów:

- Ewangelia - jako orędzie, które zwiastuje usprawiedliwienie przez Boga $\mathrm{z}$ wiary w wiarę i obdarza sprawiedliwością (Rz 1,16n);

- Chrystus - jako nasza sprawiedliwość (1 Kor 20), który został wydany za nasze grzechy i wzbudzony $\mathrm{z}$ martwych dla naszego usprawiedliwienia (Rz 4,25);

- Grzeszność - jako naturalny po upadku stan całej ludzkości - „wszyscy zgrzeszyli i brak im Bożej chwały" (Rz 3,23);

- Wiara usprawiedliwiająca grzesznika (Ga 3,6 i Rz 4,3-9);

- Sprawiedliwość Boża jako moc dla wierzącego (Rz 1,16n). „Ta sprawiedliwość w Chrystusie staje się naszą sprawiedliwością (2 Kor 5,21).

Wreszcie samo usprawiedliwienie, które staje się naszym udziałem przez Jezusa Chrystusa, którego Bóg ustanowił jako ofiarę przebłagalną, skuteczną przez wiarę ( $\mathrm{Rz} 3,25)$.

\footnotetext{
${ }^{1}$ https://ekumenia.pl/czytelnia/dokumenty-ekumeniczne/wspolna-deklaracja-w-sprawie-naukio-usprawiedliwieniu/ (dostęp: 8.11.2019).

${ }^{2}$ Część zatytułowana „Biblijne orędzie o usprawiedliwieniu” rozpoczyna się już w punkcie 8.
} 
Na marginesie warto dodać, że wygenerowanie terminów kluczowych dla zrozumienia nauki o usprawiedliwieniu ma długą historię, sięga bowiem niemal początków Reformacji wittenberskiej. Luter taką listę pojęć, które później definiuje bardziej szczegółowo, niż jest to zrobione w WD, podaje w Przedmowie do Listu do Rzymian z 1522 r.: prawo, grzech, łaska, wiara, sprawiedliwość, ciało, duch. „Bez [...] zrozumienia tych słów nigdy nie pojmiesz tego listu św. Pawła ani też żadnej innej księgi Pisma św.”3.

Czym jest samo usprawiedliwienie, definiuje punkt $11 \mathrm{WD}$ :

- odpuszczeniem grzechów (Rz 3,23-25);

- wyzwoleniem z mocy grzechu i śmierci (Rz 5,12-21);

- wyzwoleniem od przekleństwa zakonu (Ga 3,10-14);

- przyjęciem do społeczności z Bogiem już teraz, lecz w sposób doskonały dopiero w Królestwie Bożym (Rz 5,1n);

- zjednoczeniem z Chrystusem, Jego śmiercią i zmartwychwstaniem (Rz $8,1 \mathrm{nn} ; 1$ Kor 12,12).

A ,wszystko to pochodzi wyłącznie od Boga ze względu na Chrystusa, z łaski przez wiarę w Ewangelię o Synu Bożym" (Rz 1,1-3).

Punkt 12 WD opisuje sposób, w jaki realizuje się usprawiedliwienie. Streszcza je właściwie już pierwsze zdanie: „Usprawiedliwieni żyją z wiary, która pochodzi ze słowa Chrystusa" (Rz 10,17), jest ona [wiara] czynna w miłości $(\mathrm{Ga} 5,6)$, ta zaś jest owocem Ducha $(\mathrm{Ga} 5,22)^{4}$.

\section{LUTROWE PODEJŚCIE DO BIBLII}

Zanim nastąpi analiza wymienionych w punkcie 11 WD aspektów usprawiedliwienia na podstawie komentarzy Lutra, należy przypomnieć podejście Reformatora do Biblii. Przystępując do pracy z Biblią, Luter był jeszcze przywiązany do średniowiecznej egzegezy Pisma św. - poszukiwał w nim

\footnotetext{
${ }^{3}$ M. Luter, Przedmowa do Listu św. Pawła do Rzymian, w: Przedmowy do ksiag biblijnych, tłum. J. Krzyszpień, Warszawa: Ogród Ksiąg 1992, s. 54-61.

4 „Ponieważ jednak moce i żądze trapią wierzących zewnętrznie i wewnętrznie (Rz 8,35-39; Ga 5,16-21), tak że popadają w grzech $(1 \mathrm{~J} 1,8.10)$, dlatego wierzący muszą się wsłuchiwać stale na nowo w obietnice Boże, wyznawać swoje grzechy (1 J 1,9), mieć udział w ciele i krwi Chrystusa oraz być napominani do życia w zgodzie z wolą Bożą. Dlatego apostoł mówi usprawiedliwionym: Z bojaźnią i ze drżeniem zbawienie swoje sprawujcie. Albowiem Bóg to według upodobania sprawia w was i chcenie, i wykonanie (Flp 2,12n.). Radosne orędzie zachowuje jednak swoją aktualność: Przeto teraz nie ma żadnego potępienia dla tych, którzy są w Chrystusie Jezusie $(R z 8,1)$ i w których żyje Chrystus (Ga 2,20). Przez sprawiedliwy czyn Chrystusa przyszło dla wszystkich ludzi usprawiedliwienie ku żywotowi (Rz 5,18)” (WD 12).
} 
czterech sensów: dosłownego, alegorycznego, moralnego i eschatologicznego. $Z$ czasem od tego odszedł na rzecz refleksji opartej na warstwie literalnej, co oznacza tutaj przyglądanie się budowie tekstu i znaczeniom poszczególnych fraz, zwłaszcza w językach oryginalnych. Korzystał przy tym $\mathrm{z}$ nowoczesnych $\mathrm{w}$ tym okresie metod filologicznych, wypracowanych przez humanistów, a jednocześnie ze znanej od starożytności metody antologicznej - grupowania tekstów na ten sam temat i/lub używających tych samych terminów. To pomagało Lutrowi uchwycić specyficzny biblijny sposób wyrażania myśli (dzisiejsi egzegeci dopatrywaliby się w tym podejściu elementów analizy retorycznej, zastosowania zasad retoryki klasycznej i retoryki hebrajskiej oraz analizy semantycznej).

Poznanie specyfiki języka biblijnego i zgromadzenie materiału antologicznego pomagało w zastosowaniu zasady „Pismo św. interpretuje się samo". Oznacza to, że nie trzeba szukać wykładni zewnętrznej, zwłaszcza tej opierającej się na filozofii greckiej, głównie na Arystotelesie, lecz szukać wyjaśnienia poszczególnych terminów/fraz w samej Biblii. Odseparowanie rekonstrukcji pierwotnego (własnego) znaczenia tekstu od metody interpretacji pochodzącej $\mathrm{z}$ innego kręgu kulturowego, to ważna intuicja biblijna Lutra. Stoi za nią przekonanie, że język Pisma św. jest językiem, za którego pomocą przemawia Duch Święty. Trzeba się tego języka nauczyć, począwszy od rozumienia poszczególnych słów, aby potem przejść do rozumienia większych fragmentów aż po zrozumienie całego Pisma ${ }^{5}$. Język biblijny może czytelnikowi sprawiać trudności, ale nie należy się tym zniechęcać. W Przedmowie do Starego Testamentu Luter pisał:

Proszę i przestrzegam wiernie każdego pobożnego chrześcijanina, aby się nie gorszył prostą mową i dziejami, o których będzie czytał, lecz by nie wątpił, jakkolwiek licho one wyglądają, że są to słowa, dzieła, sądy i dzieje najwyższego Boskiego majestatu, mocy i mądrości ${ }^{6}$.

Charakterystyczne jest tutaj odróżnienie warstwy stylistycznej, zewnętrznej formy językowej (dziś można to nazwać strukturą powierzchniową) od treści, jakie niosą słowa (to byłaby struktura głęboka). Dla zilustrowania tego rozróżnienia Luter posługuje się obrazem Chrystusa leżącego w żłobie w pieluszkach: „Tutaj znajdziesz pieluszki i żłób, w których leży Chrystus, tutaj też kieruje pasterzy anioł. Liche i skromne są to pieluszki, lecz drogi

\footnotetext{
${ }^{5}$ H.A. Obermann, Marcin Luter człowiek między Bogiem a diabłem, tłum. E. Adamiak, Gdańsk: Wydawnictwo Marabut 1996, s. 129.

${ }^{6}$ M. Luter, Przedmowa do Starego Testamentu, w: TENŻE, Przedmowy do ksiag biblijnych, s. 18.
} 
jest skarb, który w nich leży"7. Można tu także dostrzec filologiczne dochodzenie do hermeneutyki. Nieważne, jakich słów się używa, jeśli za ich pośrednictwem można odnaleźć Chrystusa. Chrystocentryzm jest więc pierwszą zasadą hermeneutyczną Lutra. „Jeśli chcesz objaśniać dobrze i pewnie, weź przed siebie Chrystusa. On bowiem jest tym mężem, którego to wszystko [czyli ST i NT] w całości i zupełności dotyczy" - przekonuje Reformator w Przedmowie do Starego Testamentu z 1523 r. ${ }^{8}$, ale zasadę tę zauważa już wcześniej, o czym świadczy kazanie z 1515 r., w którym przestrzega, aby w egzegezie nie kierować się własnymi odczuciami i nie naginać tekstu do własnych tez, ale pozwolić, by tekst poprowadził czytelnika/egzegetę do źródła:

Kto chce czytać Biblię, musi uważać, by się nie pomylił, bowiem pismo da się rozciągać i kierować, ale niech nikt nie kieruje nim według własnego afektu, lecz prowadzi je do źródła, to znaczy do krzyża Chrystusa; wtedy z pewnością spotka Go i nie rozminie się z Nim ${ }^{9}$.

Rozwija to również później w Artykułach szmalkaldzkich II, 1,1, gdzie pojawia się jeszcze wyraźniejszy akcent soteriologiczny: „To jest pierwszy i główny artykuł: Jezus Chrystus Bóg i Pan nasz umarł z powodu grzechów naszych i zmartwychwstał dla usprawiedliwienia naszego (Rz 4,25)" ${ }^{\prime 10}$.

Kolejne dwa elementy charakterystyczne dla Lutrowej egzegezy ściśle łączą się z tą podstawową refleksją hermeneutyczną. Po pierwsze, jest to przekonanie, że wszystkie tak różne teksty biblijne, różne sposoby wyrażania myśli łączy Duch Święty, który sprawia, że z jednej strony wypowiadają się one, a z drugiej są odczytywane jako teksty rzeczywiście mówiące o Chrystusie. Innymi słowy, dzięki Duchowi Świętemu słowo Pisma św. staje się słowem Bożym. Po drugie, działanie Ducha Świetego na czytelnika, poruszanie go, sprawia, że egzegeza nabiera wymiaru nie tylko filologicznego czy naukowego, ale przede wszystkim egzystencjonalnego i budującego.

\footnotetext{
${ }^{7}$ Tamże, s. 4.

${ }^{8}$ Tamże, s. 18.

${ }^{9}$ Kazanie z 1515 r. wygłoszone w rocznicę chrztu (WA I, 52,15-18) - za: H.A. OBERMAN, Marcin Luter, s. 133.

${ }^{10}$ M. LuTER, Artykuly szmalkaldzkie, tłum. W. Niemczyk, w: Księgi wyznaniowe Kościoła luterańskiego, wyd. 3, Bielsko-Biała: Wydawnictwo Augustana 2011, s. 338.
} 


\section{CHARAKTERYSTYKA KOMENTARZY DO LISTU DO RZYMIAN I DO LISTU DO GALATÓW}

Komentarze Lutra do Listu do Rzymian i do Listu do Galatów, będące podstawą niniejszego opracowania, pochodzą z dwóch różnych epok w dziejach Reformacji wittenberskiej. Pierwszy z komentarzy należy do wczesnej twórczości Lutra, drugi - do twórczości dojrzałej. Dystans czasowy, jaki je dzieli, około 20 lat, pozwala zaobserwować zmiany w podejściu Lutra do tekstu biblijnego, związane $\mathrm{z}$ dojrzewaniem samego Reformatora i z krzepnięciem doktryny, w tym nauki o usprawiedliwieniu.

\section{Komentarz, A WŁaściWie WyKŁad Listu do RZymian}

Wykłady na temat Listu do Rzymian prowadził Luter w latach 15151516. Ich pokłosiem jest spisany i wydrukowany komentarz. Warto zauważyć, że do 1516 r. komentowany był głównie tekst łaciński, dopiero po 1516 r., kiedy ukazało się pierwsze krytyczne wydanie greckiego Nowego Testamentu Erazma z Rotterdamu, Luter mógł sięgnąć do tekstu greckiego. Nie wiadomo dokładnie, kiedy Reformator otrzymał to wydanie, wydaje się jednak, że dość szybko, bo począwszy od rozdziału 9 posługuje się już tekstem greckim, a przekład łaciński traktuje pomocniczo.

Wykład składa się z dwóch części: scholii oraz gloss. Ten sposób komentowania zaczerpnął Luter jeszcze z tradycji średniowiecznej. Tekst biblijny był pisany $\mathrm{w}$ wierszach, pomiędzy którymi zostawiano spore odległości. Tam wpisywano przede wszystkim uwagi natury gramatycznej, filologicznej, różne warianty znaczeniowe, niuanse semantyczne, czyli glossy. Scholia to właściwy komentarz ${ }^{11}$. Nie obejmuje każdego wiersza, niektóre są pomijane, inne komentowane kilka razy, $\mathrm{z}$ różnych perspektyw w powiązaniu $\mathrm{z}$ różnymi zagadnieniami, co niekiedy sprawia wrażenie chaosu. Za każdym razem Luter stara się jednak nie tracić $\mathrm{z}$ oczu kontekstu oraz głównej myśli całego listu - w Liście do Rzymian będzie to usprawiedliwienie, sprawiedliwość i rola Prawa (Zakonu).

Wykład Listu do Rzymian ma charakter nie tyle naukowy, co często mu się zarzuca, ile duszpasterski oraz egzystencjalny. Luter chętnie sięga po osobiste refleksje i własne opinie, na pewno czyni to o wiele częściej niż wcześniej, np. w pierwszym wykładzie na temat Księgi Psalmów. Takie

\footnotetext{
${ }^{11}$ W. PAUCK, General Introduction, w: Luther. Lectures on Romans, ed. and trans. W. Pauck, Louisville: Westminster John Knox Press 1961, s. XXIV-XXVI.
} 
osobiste podejście staje się wkrótce elementem charakterystycznym dla Lutrowej egzegezy. Oczywiście Reformator nie rezygnuje z tzw. Glossa Ordinaria, czyli używanych w średniowieczu komentarzy opartych na tekstach patrystycznych i scholastycznych, ale nie waha się ich krytykować czy z nimi polemizować ${ }^{12}$. Ogranicza też wybór pism Ojców Kościoła, do których sięga. Najchętniej opiera się na Augustynie, przytacza całkiem pokaźne fragmenty z jego dzieła Duch a litera, ale nie tylko, bo równie chętnie korzysta z Augustynowego komentarza do Listu do Rzymian.

\section{WyKŁAD I KOMENTARZ Do Listu Do GALATÓW}

Wbrew pozorom to wcale nie List do Rzymian był ulubionym nowotestamentowym listem Lutra. Palma pierwszeństwa należy się Listowi do Galatów. Wykłady na temat tego pisma Reformator zaczął prowadzić tuż po wykładach na temat Listu do Rzymian - od października 1516 r. do marca 1517, od początku na tekście greckim. W 1519 r. postanowił je zredagować i opublikować, uzupełniając cytatami z literatury patrystycznej i pism klasycznych, które pomagał mu gromadzić Filip Melanchton. We wrześniu 1519 r. komentarz w wersji łacińskiej został ukończony i wydany po raz pierwszy; pod względem formalnym ta wersja bardzo przypomina komentarz do Listu do Rzymian.

W $1531 \mathrm{r}$. Reformator powrócił do wykładów na temat Listu do Galatów, ale nie sięgnął po prostu po notatki z lat 1516-1517, lecz stworzył właściwie nowe dzieło, które po łacinie zostało wydane w 1535 r., a w 1539 r. po niemiecku. Nowy komentarz/wykład jest dłuższy, dużo bardziej polemiczny i bardziej usystematyzowany pod względem formalnym (komentowanie wiersza po wierszu) i doktrynalnym, za to mniej filologiczny niż wersja z 1519 r.; wielokrotnie pojawia się w nim sformułowanie „doktryna usprawiedliwienia”. Hans Dieter Betz uznał ten komentarz za wyrażający

niezwykłe i głębokie zrozumienie tego, co Paweł chciał powiedzieć. Komentarz Lutra jest czymś więcej niż komentarzem naukowym do Ga; jest odtworzeniem listu w XVI w. Luter mówi tak, jak powiedziałby Paweł, gdyby żył w czasie, gdy Luter prowadził swoje wykłady ${ }^{13}$.

I na tym komentarzu będzie oparta refleksja dotycząca usprawiedliwienia jako wyzwolenia od przekleństwa Zakonu (Ga 3,10-14).

12 D.M. Whitford, Luther: A Guide for the Perplexed, London-New Delhi-New YorkSidney: T \& T Clark International 2011, s. 26.

${ }^{13}$ H.D. Betz, Galatians, Philadelphia: Fortress Press 1979, s. XV. 


\section{ISOTA USPRAWIEDLIWIENIA WEDŁUG KOMENTARZY LUTRA I WSPÓLNEJ DEKLARACJI}

Strukturę tej części artykułu, jak zapowiedziano, będą stanowiły aspekty usprawiedliwienia wymienione w punkcie $11 \mathrm{WD}$, przy których autorzy podali sigla źródłowych tekstów biblijnych. Zostaną one skomentowane z perspektywy komentarzy Lutra. Pozwoli to zauważyć zarówno zbieżności, jak i rozbieżności w ujęciu usprawiedliwienia przez Lutra i przez autorów WD, które zostaną zaprezentowane syntetycznie w podsumowaniach każdego $\mathrm{z}$ omawianych passusów.

\section{USPRAWIEDLIWIENIE JAKO ODPUSZCZENIE GRZECHÓW}

$\operatorname{Rz} 3,23-25^{14}$

${ }^{23}$ Albowiem wszyscy zgrzeszyli i nie dostawa im chwały Bożej.

${ }^{24}$ Usprawiedliwieni darmo przez łaskę jego, przez odkupienie, które jest w Chrystusie Jezusie,

${ }^{25}$ którego Bóg wystawił ubłaganiem przez wiarę w krwi jego, ku okazaniu sprawiedliwości swojej dla odpuszczenia przeszłych grzechów

Analizując ten fragment, Luter wychodzi od rozważań semantycznych na temat wyrażenia „brak chwały Bożej”. Rozbija je na dwa elementy: pierwszy to „brak chwały”, drugi zaś „chwała Boża”. „Brak chwały” oznacza brak sprawiedliwości, którą człowiek mógłby się chlubić przed Bogiem. Nie chodzi tu jednak tylko o sprawiedliwość, bo rzeczownik „brak” należy potraktować szerzej - jako wskazanie, że człowiek nie ma niczego, czym mógłby się przed Bogiem i w Bogu chlubić. To prowadzi do uświadomienia sobie, że jedyną w istocie chlubą człowieka jest Bóg (Ps 3,4); wszystko inne - w tym uczynki, które uchodzą za sprawiedliwe - są czymś, z czego można być dumnym, ale tylko przed ludźmi. W ten sposób za Augustynem Luter rozróżnia sprawiedliwość przed Bogiem i sprawiedliwość przed ludźmi.

Zwrot „chwała Boża” nie oznacza chwały jako jednego z atrybutów Boga. Jak już zauważono, jest to sprawiedliwość Boża, a ta jest darem, który sprawia, że człowiek może chlubić się nie tylko przed Bogiem, ale i w Bogu,

\footnotetext{
${ }^{14}$ Tłumaczenie tekstów biblijnych z Listu do Rzymian za Biblią Jakuba Wujka (1599), tłumaczeniem polskim najbliższym, jak się wydaje, Biblii łacińskiej, na której w komentarzu do Listu do Rzymian opierał się Luter. Dla ułatwienia rozumienia tekstu staropolskiego, została zastosowana transkrypcja typu „B” oryginalnego tekstu z XVI wieku dokonana przez ks. J. Frankowskiego.
} 
a nawet samym Bogiem, dawcą sprawiedliwości. Luter rozumie więc chwałę dynamicznie, a jej brak promisoryjnie: świadomość braku chwały/sprawiedliwości jest wstępem do uchwycenia się obietnicy usprawiedliwienia, czyli obdarowania człowieka Bożą sprawiedliwością.

Komentarza właściwie nie doczekał się strategiczny w tym fragmencie w. 24. Jest on wspominany przy omawianiu w. 21, a krótkiemu wyjaśnieniu nadano charakter polemiczny: „Nie tak udziela On darmo łaski, że niewymagane jest żadne zadośćuczynienie, ale dał za nas zadośćuczynienie Chrystusa, aby tym, za których ktoś inny zadośćuczynił, udzielić darmo łaski"15.

Przy lekturze linearnej - a taką, oczywiście, Luter zakłada - wyjaśnienie to należy umieścić w kontekście w. 23. Wtedy widać, że Bóg jako źródło wszelkiej sprawiedliwości, udziela jej hojnie jako daru, czyli za darmo. Pojawia się jednak konieczność wyjaśnienia, jak rozumieć owo „za darmo”. Dla Lutra to właściwie eliptyczny opis udziału ludzi w pozyskiwaniu sprawiedliwości. Sprawiedliwość zostaje ludziom podarowana przez Boga bez żądania jakiejkolwiek zapłaty, dlatego że wcześniej została ona pozyskana dla ludzi dzięki ,zadośćuczynieniu Chrystusa”.

O w. 25 Luter wypowiada się w glossach jako o wierszu tajemniczym. Aby go wyjaśnić, dzieli go na poszczególne frazy, co do dziś jest praktyką typową dla egzegezy.

Fraza „Jego Bóg uczynił (ustanowił/wystawił)” ma wyrażać preegzystencjalną ideę zbawczą, która realizuje się w inkarnacji: „od wieczności ustanowił i oto teraz wszystkim okazał".

We frazie „Jako ofiarę przebłagalną w wierze” jest akcentowana przede wszystkim wiara jako warunek uznania ofiary Chrystusa za ofiarę przebłagalną. Oznacza to, że ofiara Chrystusa jest skuteczna tylko dla tych, którzy wierzą.

„Dla okazania swojej sprawiedliwości” oznacza cel, czyli usprawiedliwienie. Jest ono możliwe tylko wtedy, gdy człowiek, patrząc na sprawiedliwość Bożą, uświadamia sobie własną niesprawiedliwość i potrzebę przyjęcia sprawiedliwości Chrystusa: „Czegoż bowiem innego ma dowieść fakt, że Chrystus cierpiał i przez cierpienie stał się przebłaganiem, jak nie tego, iż jesteśmy niesprawiedliwi [...] i u Boga szukamy naszej sprawiedliwości”.

Stosunkowo wiele miejsca poświęca Luter wyrażeniu „grzechy wcześniej popełnione". Najpierw w glossach zaznacza, że oznacza ono grzechy, które zostały popełnione, zanim człowiek uświadomił sobie potrzebę usprawiedliwienia, czyli okazania Bożej sprawiedliwości. Te grzechy „Bóg znosił cierp-

\footnotetext{
${ }^{15}$ Wszystkie cytaty z wykładu Listu do Rzymian za: M. Luter, Wykład Listu do Rzymian, tłum. I. Slawik, Dzięgielów: Wydawnictwo Warto 2010.
} 
liwie, by przebaczyć, przebacza je, by okazać swą sprawiedliwość". Następnie w scholiach Reformator tłumaczy je w sposób bardziej wyczerpujący, posługując się diatrybą:

Bóg przez przebaczenie grzechów, które popełniliśmy wcześniej, ukazuje się wszystkim jako ten, który wszystkich usprawiedliwia [...] który jest sprawiedliwy i ma moc usprawiedliwiać [...] Powiedziane jest „przeszłe grzechy”, bo nie przebacza wszystkich grzechów, aby kto nie powiedział: skoro grzechy przez Chrystusa są usunięte, to róbmy, co chcemy, odtąd nikt nie może grzeszyć.

Oczywiście za Pawłem Luter zaprzecza takiemu antynomizmowi, nazywając go ,głupim i cielesnym”.

Kontynuując tę antynomistyczną polemikę, Reformator przechodzi od razu do w. 31 i wyjaśnia, że w tym kontekście „umacnianie zakonu” należy rozumieć jako wypełnianie go z wiarą. Tutaj do głosu dochodzi rozróżnienie między uczynkami prawa i wypełnieniem prawa. Reformator odnosi się do niego w wielu miejscach, tu akurat nie expressis verbis, ale warto je streścić. Uczynki prawa należą do sfery sprawiedliwości ludzkiej - to czyny nakazane albo zakazane przez prawo, które człowiek wypełnia, bo musi, boi się lub chce zyskać ludzki szacunek. Nie wkłada w to jednak serca. „Bóg zaś sądzi według serca. Dlatego jego prawo żąda serca i nie zadowala się uczynkami; co więcej, uczynki spełniane bez udziału serca"16 - to ułuda i kłamstwo, a więc grzech. Przez taki uczynek prawa człowiek nie staje się sprawiedliwy przed Bogiem, wręcz przeciwnie. Natomiast ,wypełniać prawo oznacza [...] spełniać jego uczynki z ochotą i miłością, dobrowolnie i bez przymusu prawa, żyć po Bożemu i poprawnie, jakby nie było prawa i kary. Takie pragnienie wkłada w serce Duch św." ${ }^{17}$, jest to więc możliwe wyłącznie dla wierzącego, który pragnie usprawiedliwienia nie na podstawie spełniania uczynków prawa, lecz na podstawie sprawiedliwości Chrystusa.

\section{Podsumowanie}

Usprawiedliwienie jako przebaczenie grzechów ujęte w Lutrowym komentarzu do $\mathrm{Rz}$ 3,23-25 jest obdarowaniem człowieka, który niczym przed Bogiem i w Bogu nie może się chlubić, sprawiedliwością Bożą rozumianą dynamicznie jako dar i zwierciadło, w którym człowiek rozpoznaje własną niesprawiedliwość. Sprawiedliwość Boża jest darem dlatego, że od niesprawiedliwego człowieka stającego przed Bogiem nie wymaga się zadość-

\footnotetext{
${ }^{16}$ M. Luter, Przedmowa do Listu do Rzymian, s. 56.

${ }^{17}$ Tamże, s. 57.
} 
uczynienia za grzechy. Zadośćuczynienie dokonało się już w zbawczym dziele Jezusa Chrystusa, ale jest ono skuteczne tylko dzięki wierze. Luter za Pawłem podkreśla, że zadośćuczynienie obejmuje grzechy przeszłe, a więc te, które zostały popełnione, zanim człowiek uświadomił sobie potrzebę usprawiedliwienia i przyjęcia daru Bożej sprawiedliwości. Przyjęcie daru sprawiedliwości nie oznacza libertynizmu, lecz zmianę postawy i postrzegania prawa, które może być teraz wypełniane dobrowolnie i z miłością, cały czas jednak przy świadomości, że nie w uczynkach prawa kryje się istota usprawiedliwienia. „Usprawiedliwiony przed Bogiem jest ten, kto prosi o usprawiedliwienie i nie uważa się za sprawiedliwego".

\section{WYZWOLENIE Z MOCY GRZECHU I ŚMIERCI}

Rz 5,12-21

${ }^{12}$ Dlatego jako przez jednego człowieka grzech na ten świat wszedł, a przez grzech śmierć, i tak na wszystkie ludzie śmierć przeszła, w którym wszyscy zgrzeszyli.

${ }^{13}$ Albowiem aż do zakonu grzech był na świecie, a grzech nie był przyczytany, gdy zakonu nie było.

${ }^{14}$ Ale śmierć królowała od Adama aż do Mojżesza też nad tymi, którzy zgrzeszyli na podobieństwo przestępstwa Adama, który jest kształtem przyszłego.

${ }^{15}$ Ale nie jako przestępstwo, tak i dar; albowiem jeźli przestępstwem jednego wiele ich pomarło, daleko więcej na wiele ich opłynęła łaska Boża i dar w łasce jednego człowieka Jezusa Chrystusa.

${ }^{16}$ A nie jako przez jeden grzech, tak i dar. Albowiem sąd wprawdzie z jednego ku potępieniu, a łaska $\mathrm{z}$ wiela występków ku usprawiedliwieniu.

${ }^{17}$ Albowiem jeźli jednego przestępstwem śmierć królowała przez jednego, daleko więcej ci, którzy obfitość łaski i darowania, i sprawiedliwości biorą, w żywocie królować będą przez jednego Jezusa Chrystusa.

${ }^{18}$ Przeto jako przez jednego przestępstwo na wszystkie ludzie ku potępieniu, tak i przez jednego sprawiedliwość na wszystkie ludzie ku usprawiedliwieniu żywota.

${ }^{19}$ Bo jako przez nieposłuszeństwo jednego człowieka wiele ich stało się grzesznymi, tak i przez posłuszeństwo jednego wiele ich stanie się sprawiedliwymi.

${ }^{20}$ A zakon na czas wszedł, aby obfitowało przestępstwo; lecz gdzie obfitowało przestępstwo łaska więcej obfitowała.

${ }^{21}$ Aby jako grzech królował na śmierć, tak też łaska królowała przez sprawiedliwość ku żywotowi wiecznemu przez Jezusa Chrystusa, Pana naszego.

W komentarzu do tego fragmentu Luter nie stosuje częstych gloss filologicznych; przemyca je w tekście, np. zastanawiając się, czy zaimek w za- 
kończeniu w. 12 należy potraktować jako masculinum czy jako neutrum ${ }^{18}$, albo czy wyrażenie „przez jednego człowieka” rozumieć indywidualnie, czy jako frazę upowszechniającą (,przez każdego człowieka”). Glossy mają raczej charakter semantyczny lub są notatkami, które w mniejszym lub większym stopniu zostaną uwzględnione w scholiach. Uwagę zarówno w glossach, jak i w scholiach zwraca polemika ze scholastykami oraz bardzo częste odwołania do Augustyna.

Rozważania w tekście głównym rozpoczynają się wyjaśnieniem różnic między grzechem pierworodnym oraz grzechami faktycznymi (aktualnymi). Tylko w przypadku Adama grzech pierworodny był jednocześnie grzechem faktycznym:

[...] grzech pierworodny jest własnym grzechem Adama, jego grzechem faktycznym [...], wyrokiem skazującym spowodowanym przez to przestępstwo [...] Grzech pierworodny jest równoznaczny z grzechem faktycznym, w którym Adam zgrzeszył. Grzech ten niosą odtąd wszystkie jego dzieci i z jego powodu są obarczone wyrokiem. Gdyż Adam wraz ze swą naturą przenosi na wszystkich swój grzech, ponieważ on sam przez swój grzech stał się faktycznie grzesznikiem [...], tak i płodzi jedynie grzeszników [...] tzn. tych, którzy wykazują skłonność do złego i niechęć wobec dobra.

Istotnym rozróżnieniem jest obserwacja na podstawie wyrażeń użytych przez Pawła, że grzech pierworodny jest jedynym, który nie pochodzi od człowieka, lecz do niego/na niego przychodzi. Wszystkie inne, aktualne grzechy/ przestępstwa wychodzą już od ludzi.

Wyjaśniając w. 15, Luter definiuje rolę prawa. Nie chodzi o to, że przed prawem grzech na świecie nie istniał, ani o to, że prawo - jeśli jego zakazy i nakazy będą spełnione - pozwala na zniesienie grzechu, ale o to, że dzięki prawu grzechy dotąd ukryte stały się jawne i człowiek może sobie uświadomić własną niesprawiedliwość i potrzebę innego niż daje prawo usprawiedliwienia - usprawiedliwienia Chrystusowego. Do tego wątku Reformator powraca przy komentarzu do w. 20, gdzie za Augustynem rozwija myśl o uświadamiającej, a nie usprawiedliwiającej roli prawa:

Prawo nie zostało dane, by ożywiać - tylko łaska ożywia przez wiarę - lecz by pokazać, jak wieloma i jak mocnymi łańcuchami grzechów są spętani i uwięzieni ci, którzy twierdzili, że zakon należy wypełnić własnymi siłami.

18 „Do końca nie wiadomo, czy w tekście greckim występuje masc. czy neutr. Dlatego wygląda to tak, jakby apostoł chciał, by odczytywano tu jedno i drugie" (s. 182). Nie wiadomo też, czy Luter miał przed sobą tekst grecki - wydaje się, że nie. 
Dodaje do tego obrazowe porównanie, właściwie miniprzypowieść, która mogłaby się znaleźć raczej w kazaniu niż w naukowym komentarzu: Prawo podobne jest do lekarza, który przychodzi do chorego, ale nie potrafi mu pomóc, choć chory bardzo na tę pomoc liczy. Wtedy chory z żalem i rozczarowaniem wymawia lekarzowi, że przyszedł nie, aby wyleczyć, lecz powiększyć zwątpienie chorego.

W w. 15 Luter akcentuje też pozorne rozróżnienie między łaską a darem i wyjaśnia, że jeśli usprawiedliwiony od Boga otrzymał łaskę, to właściwie otrzymał od Niego dar, bo łaska nie została mu udzielona za zasługi, ale właśnie jako podarunek, „który Ojciec dał Chrystusowi, by ten podarował go ludziom". Łaska zatem i dar w kontekście usprawiedliwienia oznaczają w istocie to samo - sprawiedliwość, która została dana ludziom za darmo przez Chrystusa. Paweł rozróżnia te dwa rzeczowniki i obok daru wprowadza łaskę tylko dlatego, aby uzmysłowić odbiorcom, że daru sprawiedliwości nie należy pojmować tak, jakby to był podarunek ofiarowany przez przyjaciela. Przeciwnie - sprawiedliwość zostaje ofiarowana, kiedy ludzie jako grzesznicy - są nieprzyjaciółmi Boga. Dlatego właśnie należy ją traktować jako daną miłosiernie łaskę.

Rozbudowana Pawłowa analogia w ww. 16-19 została przez Lutra (za Augustynem) bardzo klarownie streszczona, aby pokazać, na czym w istocie polega usprawiedliwienie jako przyjęcie sprawiedliwości Chrystusa:

Adam stał się dla wszystkich swoich potomków, którzy przecież nie jedli z drzewa, przyczyną śmierci, którą sprawiło zjedzenie owocu. Chrystus jest dla wszystkich, którzy się od niego wywodzą, choć nie dokonali żadnego sprawiedliwego czynu, rozdawcą sprawiedliwości, jaką wszystkim na krzyżu ofiarował. Innymi słowy - umieramy, jakbyśmy zgrzeszyli jak Adam (choć nie jemy owocu), i żyjemy, jakbyśmy w podobny do Chrystusa sposób czynili sprawiedliwość [choć oczywiście jej nie czynimy].

Analogia ta jednak ani jej rozwinięcie w w. 21 w finalnym zdaniu porównawczym: „jak grzech królował w śmierci ... tak łaska królowała ku życiu ..." nie powoduje zrównania grzechu i łaski czy śmierci i życia. Tej myśli Luter tu już nie rozwija, ponieważ - jak się wydaje - zasygnalizował ją przy analizie w. 15. i zaznaczył, że „Apostoł powtarza to samo używając wciąż nowych i nowych słów, by wychwalać wielkość i obfitość łaski” (ww.1518). Nierówność grzechu i łaski polega na tym, że jeden grzech jednego człowieka sprowadził śmierć na wszystkich ludzi - teraz widać zasadność wstępnych rozważań na temat grzechu pierworodnego oraz grzechów aktualnych, ale łaska jako dar przezwyciężyła nie tylko ten jeden grzech jednego człowieka, lecz wszystkie grzechy wielu ludzi: 
Gdyż jeśli grzech był tak potężny, że zgubił wielu, a nawet wszystkich, to łaska jest $\mathrm{o}$ wiele potężniejsza, bo jedna $\mathrm{z}$ wielu grzechów zbawia wielu, a nawet wszystkich, jeśli wszyscy tego chcą.

\section{Podsumowanie}

W podejściu do Rz 5,12-21 Lutra i autorów WD widać niewielką różnicę. Chodzi o inne rozłożenie akcentów oraz uwagę poświęconą wszystkim elementom tego tekstu. Autorzy WD, opierając się na ww. 15-19, a zwłaszcza finalnym 21, akcentują element pozytywny - usprawiedliwienie jest wyzwoleniem z mocy grzechu i śmierci. Luter, koncentrując się na roli prawa w w. 15 i 20, pozornie akcentuje aspekt negatywny - prawo nie ma mocy, aby wyzwolić człowieka z mocy grzechu i śmierci. Ale dzięki temu tłu łatwiej jest Reformatorowi naświetlić nie tylko wyższość łaski nad grzechem i życia nad śmiercią, ale również donatywny charakter łaski.

\section{WYZWOLENIE OD PRZEKLEŃSTWA ZAKONU}

Ga $3,10-14^{19}$

${ }^{10}$ Albowiem ile ich jest z uczynków zakonu, pod przeklęctwem są, bo napisano: Przeklęty każdy, który by nie trwał we wszytkich rzeczach, które napisane są w księgach zakonu, aby je czynił

${ }^{11}$ A iż przez zakon żaden nie bywa usprawiedliwion u Boga, jawnoć jest, gdyż sprawiedliwy z wiary żyć będzie.

${ }^{12}$ A zakon nie jest ci z wiary, ale człowiek, który by im dość uczynił, w nich żyć będzie.

${ }^{13}$ Lecz Krystus nas odkupił od przeklęctwa zakonu, gdyż za nas stał się przeklęctwem, albowiem napisano jest: Przeklęty którykolwiek wisi na drzewie,

14 aby w poganach błogosławieństwo Abrahamowe było w Krystusie Jezusie i abyśmy obiecanego Ducha wzięli przez wiarę.

Jak wspomniano, Komentarz do Listu do Galatów z 1535 (1539) r. jest o wiele bardziej systematyczny pod każdym względem niż wykład Listu do Rzymian. O ile wcześniej można było obserwować pewne zalążki myśli reformacyjnej (np. Prawo - Ewangelia), o tyle tutaj idee reformacyjne są w pełni obecne, choć nie zawsze wyrażane expressis verbis.

\footnotetext{
${ }^{19}$ Ponieważ Komentarz do Listu do Galatów powstał już po wydaniu Biblii Lutra (1534), opartej na tłumaczeniu z języków oryginalnych, tekst polski zostanie zacytowany z Biblii brzeskiej (1563). Podobnie jak przy cytatach z Biblii Wujka, również tutaj użyto transliteracji uproszczonej i uwspółcześnionej pisowni.
} 
Lutrowa analiza w. 10 rozpoczyna się od rozróżnienia między prawością (sprawiedliwością) cywilną, świecką, obywatelską a sprawiedliwością duchową, które często są mylone. Słychać tu echa wcześniejszego oddzielenia sprawiedliwości ludzkiej i sprawiedliwości Bożej oraz nauki o dwóch regimentach, która źle rozumiana wykorzystywana jest w walce przeciw Reformacji; stąd też wyraźnie polemiczny ton komentarza:

[...] nasi przeciwnicy twierdzą, jakobyśmy nauczali, że rządy nie muszą być uznawane, albo jakbyśmy faworyzowali bunty przeciw władzy i potępiali wszystkie prawa. Wyrządzają nam w ten sposób wielką krzywdę, ponieważ my wyraźnie rozróżniamy między sprawami świeckimi i duchowymi. Świeckie prawa i obrzędy są Błogosławieństwem Boga tylko dla tego życia. Ale jeśli chodzi o życie wieczne, to doczesne błogosławieństwa nie są wystarczające ${ }^{20}$.

Po tym polemicznym wstępie Luter przechodzi już do tekstu; bada, w jaki sposób Paweł używa cytatu z Pwt i zestawia słowa Mojżesza: „Każdy, kto nie wypełnia wszystkiego, co jest zapisane w Księdze Prawa, jest przeklęty" ze słowami Pawła: „Każdy, kto spełnia uczynki prawa, jest przeklęty”. Na pierwszy rzut oka cytaty wydają się sprzeczne, Reformator jednak udowadnia, że oba stwierdzenia są spójne. Argumentację opiera na przytoczonym wcześniej odróżnieniu czynienia [uczynków] prawa i wypełniania prawa. Czynienie [uczynków] prawa jest grzechem, bo motywuje je chęć uzyskania sprawiedliwości bez wiary w Chrystusa. Ci zatem, którzy czynią prawo, „zaprzeczają sprawiedliwości Boga, Jego miłosierdziu i Jego obietnicom”, zgodnie z Rz 10,3 ustanawiają $\mathrm{w}$ ten sposób własną sprawiedliwość i nie poddają się sprawiedliwości Boga. W rzeczywistości taka sprawiedliwość jest „bałwochwalstwem i bluźnierstwem przeciw Bogu”, innymi słowy: „przekleństwem”.

Zakładając, że odbiorcy komentarza wiedzą, jaką funkcję pełni prawo, Luter przypomina, że „Bóg od początku wiedział, że nie możemy wypełnić prawa, dlatego zapewnił [nam] drogę zbawienia". Następne rozważania ujęte są sylogistycznie. Po pierwsze, inna niż dzięki wypełnianiu prawu droga zbawienia opiera się na wierze w Chrystusa. Po drugie, dzięki tej wierze Duch Święty oświeca nas, abyśmy mogli zacząć wypełniać prawo - tzn. kochać Boga i bliźniego. Wiara w Jezusa Chrystusa oznacza zatem w istocie wypełnianie prawa. Bez wiary „nie można nawet podnieść palca, by zadowolić Boga”. Innymi słowy: prawdziwie wypełniają prawo ci, „których wiara w Chrystusa pociąga, by czynić prawo".

\footnotetext{
${ }^{20}$ Wszystkie cytaty z Komentarza do Listu do Galatów według Commentary on the Epistle to the Galatians, https:/www.gutenberg.org/files/1549/1549-h/1549-h.htm (dostęp: 10.10.2019).
} 
Dużo miejsca zostało poświęcone napiętnowaniu „obłudników”, którzy spełniając mechanicznie dobre uczynki, zamiast „wypełniać prawo, łamią je”. Do głosu dochodzi tu soczysty język Lutra:

Kto szuka uczynków sprawiedliwości, zaprzecza Bogu i staje się bogiem. Jest antychrystem, ponieważ przypisuje swoim dziełom wszechmocną zdolność do pokonania grzechu, śmierci, diabla, piekła i gniewu Bożego.

Przeplatając pozytywne opisy „prawdziwych sprawców prawa” z negatywnymi charakterystykami „obłudników”, Luter konkluduje, że Mojżesz wymagał doskonałego wypełnienia prawa, co jest niemożliwe. Dlatego potępił tych, którzy wypełniają je niedoskonale, bez wiary i bez Ducha Świętego. To samo zrobił Paweł, który niedoskonałe wypełnianie prawa bez wiary i bez Ducha Świętego nazwał spełnianiem uczynków prawa. Od takiego przekleństwa wyzwolić człowieka może tylko Chrystus:

Tylko Chrystus może uczynić nas niewinnymi [...] Po pierwsze, przez przebaczenie naszych grzechów i przypisanie nam Jego sprawiedliwości. Po drugie, przez dar Ducha Świętego, który rodzi w nas nowe życie i działanie.

Dalsza część komentarza do w. 10 jest poświęcona analizie tekstów biblijnych, które mówią o wierze (jak powiedziano, Luter stasuje tu metodę antologiczną) i polemice $\mathrm{z}$ oponentami. Pojawia się też charakterystyczny Lutrowy element egzystencjalny, oparty - jak można się domyślać - na własnym doświadczeniu:

Wiara przenika wszystkie uczynki wierzącego, tak jak boskość Chrystusa przenika Jego człowieczeństwo. Abraham został uznany za sprawiedliwego, ponieważ wiara przenikała całą jego osobowość i każde jego działanie.

Wierszowi 11 nie poświęcono wiele miejsca, tym bardziej że za komentarz do niego można uznać fragment, który pojawił się przy analizie tekstów poświęconych wierze:

W innych fragmentach, w których wspomina się o działaniu, Pismo św. zawsze mówi o dziele inspirowanym wiarą: „Zrób to, a będziesz żył” oznacza najpierw miej wiarę w Chrystusa, a Chrystus pozwoli ci działać i żyć.

Zdanie „Prawo nie jest z wiary” staje się okazją do kolejnej polemiki ze scholastykami, którzy czynnika usprawiedliwiającego upatrują w miłości. Luter wyjaśnia, że to prawo nakazuje miłość, o czym świadczy przede 
wszystkim przykazanie miłości. Miłość Boga natomiast polega na przestrzeganiu Jego przykazań (Wj 20,6). Wynika stąd, że tak pojmowana miłość jest elementem prawa. Tymczasem usprawiedliwienie nie dokonuje się dzięki prawu, a zatem nie dokonuje się też dzięki miłości wynikającej z prawa, lecz wyłącznie dzięki wierze w Chrystusa.

Dalsza analiza opiera się na szczegółowym wyjaśnieniu, na czym polega sprawiedliwość oparta na prawie i sprawiedliwość oparta na wierze.

Sprawiedliwość prawa jest wypełnianiem prawa zgodnie ze słowami: Kto je [przepisy prawa] czyni, będzie w nich [dzięki nim] mieszkał [czyli żył]. Sprawiedliwość wiary polega na wierze w Ewangelię, zgodnie ze słowami: sprawiedliwy z wiary żyć będzie. [...] Kiedy wierzymy w Chrystusa, żyjemy wiarą. Kiedy wierzymy w Prawo, możemy być aktywni, ale nie mamy życia, bo funkcją prawa nie jest dawanie życia. Funkcją prawa jest zabijanie.

Ta okrutna diagnoza wynika, oczywiście, z przekonania, że nie ma nikogo, kto by mógł tak doskonale wypełnić prawo, aby okazać się sprawiedliwym i żyć dzięki tej sprawiedliwości. Kto sądzi, że może w ten sposób osiągnąć sprawiedliwość, grzeszy przeciw pierwszemu przykazaniu, ponieważ taka sprawiedliwość przynależy tylko Bogu. Jak widać, w innych słowach Luter powraca do wątku fałszywych wykonawców prawa. Powraca też do „prawdziwych sprawców prawa", czyli usprawiedliwionych dzięki wierze, którzy nie musza obawiać się podlegania prawu; nie są oni przez prawo przeklęci, ponieważ ze względu na sprawiedliwość Chrystusa nie przypisuje się im grzechów. Przeciwnie - jest im przypisana sprawiedliwość Chrystusa, czyli doskonałe wypełnienie prawa.

Analiza w. 13 rozpoczyna się od polemiki z Hieronimem „i jego naśladowcami”, którzy próbują wybrnąć ze znieważającego, w ich mniemaniu, stwierdzenia, że Chrystus stał się przekleństwem. Pawłowemu stwierdzeniu zasadniczy sens nadaje jednak dopowiedzenie „za nas”, które wskazuje wyraźnie, że Chrystus został przeklęty i zasługiwał na powieszenie nie dlatego, że popełnił jakąś zbrodnię. Chrystus jest niewinny, nie ma żadnej osobistej winy, ale zajął miejsce innych grzeszników, którzy zasługują na śmierć. Wziął na siebie ich grzechy i za nie umarł na krzyżu. Oznacza to, że kiedy Chrystus wziął na siebie cudze grzechy, stał się

grzesznikiem obciążonym grzechami Pawła, który był bluźniercą, Piotra, który się Go zaparł, Dawida, który dopuścił się cudzołóstwa i morderstwa [...] Prawo zaliczyło Go do grzeszników, osądziło i powiesiło za grzeszników. 
Dalej mieszają się elementy egzystencjalne z polemicznymi. Luter siebie i swoich odbiorców nazywa grzechami Chrystusa, którego

bezgrzeszność została skalana grzesznością świata [...] nasze grzechy musiały stać się grzechami Chrystusa, bo inaczej zginęlibyśmy za zawsze [...] Jeśli Chrystus poniósł karę za nasze grzechy, nie poniesiemy jej my. Ale jeśli Chrystus nie jest winny naszych grzechów i ich nie poniósł, to znaczy, że my musimy je ponieść i za nie umrzeć.

Na gruncie soteriologicznym zatem w stwierdzeniu Pawła, że Chrystus stał się przekleństwem, nie ma nic bluźnierczego ani bardziej gorszącego niż w równie absurdalnym stwierdzeniu, że „Syn Boży umarł”. Można by się ewentualnie dopatrywać zgorszenia w warstwie literalnej, ale - jak już stwierdzono - według Lutra ta warstwa nie rozstrzyga o prawdziwym znaczeniu, jest jedynie pieluchą, która owija Chrystusa.

W analizie w. 13 widać też dojrzałą już dialektykę Lutra. Z jednej strony „grzechy całego świata, przeszłości, teraźniejszości i przyszłości przylgnęły do Chrystusa i go potępiły", z drugiej

ponieważ Chrystus jest Bogiem, miał wieczną i niezwyciężoną sprawiedliwość. [...] Grzech świata i sprawiedliwość Boga spotkały się w śmiertelnej walce. Grzech świata wściekle zaatakował Bożą sprawiedliwość, ale Boża sprawiedliwość jest nieśmiertelna i niezwyciężona [...] Tyran - grzech, który ujarzmia wszystkich, rzuca się na Chrystusa. Ale sprawiedliwość Chrystusa jest nie do pokonania. Wynik starcia jest nieunikniony: grzech zostaje pokonany, a sprawiedliwość zwycięża i króluje na wieki.

W ten sam sposób została pokonana śmierć, nazwana metaforycznie „cesarzem świata, powalającym wszystkich ludzi”. Chrystus ma życie nieśmiertelne, które zwyciężyło śmierć, a zatem „Chrystus jest śmiercią śmierci”. Właściwie to wyjaśnienie można odnieść również do Rz 5,15-21 i Lutrowego stwierdzenia o nierównowadze grzechu i łaski oraz śmierci i życia. W komentarzu do Listu do Rzymian nie padły jednak słowa i tak wyraziste metafory o przewadze łaski i życia.

Końcowa refleksja nad tym wierszem, przeplatana z polemikami, jest poświęcona wierze, jej treści rozpatrywanej w kontekście Ga 3,13 oraz jej zbawczym skutkom. Wiara i wyznawanie, że Chrystus jest Bogiem, jest $\mathrm{w}$ istocie wiarą, że pokonanie grzechu, śmierci i gniewu Bożego nie tylko nie jest dziełem stworzenia, ale jest dziełem Bożym, bo tylko Bóg 
może znieść grzech, zniszczyć śmierć i usunąć przekleństwo prawa [...]. Kiedy słyszymy, że Chrystus został dla nas przekleństwem, uwierzmy mu z radością $\mathrm{i}$ pewnością. Przez wiarę Chrystus zamienia się z nami miejscami: On dostaje nasze grzechy, my otrzymujemy Jego świętość. Tylko przez wiarę możemy stać się sprawiedliwi, ponieważ wiara przenosi nas $\mathrm{w}$ bezgrzeszność Chrystusa. Im bardziej w to wierzymy, tym pełniejsza będzie nasza radość.

Wiersz 14 jest dokończeniem w. 13, dlatego Luter w pierwszej części analizy nawiązuje do Chrystusa jako przekleństwa: „aby stać się błogosławieństwem dla wszystkich narodów, Chrystus musiał stać się przekleństwem i w ten sposób usunąć przekleństwo z narodów ziemi”. To stwierdzenie Luter ujmuje również w kategoriach egzystencjalnego wezwania, które może budzić emocje, jeśli rozpatruje się je tylko w warstwie językowej. Reformator nawołuje, aby stawać się mistrzami w „przenoszeniu grzechów, śmierci i wszelkiego zła z nas samych na Chrystusa", ale dodaje też drugi człon, soteriologiczny - i [w przenoszeniu] „sprawiedliwości i błogosławieństwa Chrystusa na nas samych".

Wzmianka o Duchu Świętym jest rozpatrywana przede wszystkim w kontekście wiary. Obiecanego Ducha można nawet utożsamić z wiarą, ponieważ tak wiara, jak i otrzymanie Duchu opiera się na obietnicach Boga. Ponadto obietnica Ducha nie jest warunkowana żadnymi zasługami, podobnie jak zasług nie wymaga dar usprawiedliwienia, który, jak Duch, oznacza tu wolność od „prawa, grzechu, śmierci, przekleństwa, piekła i sądu Bożego”.

Podsumowanie

Rozumienie usprawiedliwienia jako wyzwolenia od przekleństwa zakonu w Lutrowym komentarzu do Listu do Galatów jest bardzo chrystocentryczne, oparte na analizie pozornie bluźnierczego i absurdalnego stwierdzenia, że to Chrystus stał się dla nas przekleństwem. W tym stwierdzeniu najlepiej została odzwierciedlona dialektyczna chrystologia: Chrystus, mający własną/ osobistą Bożą sprawiedliwość, zdolność do doskonałego wypełnienia prawa, został przez to prawo przeklęty i ukarany jako grzesznik, ponieważ wziął na siebie grzechy wszystkich ludzi. Dzięki aktowi przyjęcia grzechów przez Chrystusa przekleństwo zakonu zostało zdjęte z ludzi. Co więcej, przenosząc swoje grzechy na Chrystusa, ludzie jednocześnie otrzymują Jego sprawiedliwość i świętość, a tym samym zdolność do doskonałego wypełnienia prawa. Owa zdolność jest oparta na wierze, która jest darem, i dzięki niej, podobnie jak dzięki Duchowi Świętemu, w człowieku rodzi się nowe życie. 
PRZYJĘCIE DO SPOŁECZNOŚCI Z BOGIEM JUŻ TERAZ,

LECZ W SPOSÓB DOSKONAEY DOPIERO W KRÓLESTWIE BoŻyM

Rz 5,1-2

${ }^{1}$ Będąc tedy z wiary usprawiedliwieni, pokój ku Bogu miejmy przez Pana naszego Jezusa Chrystusa,

2 przez którego też przez wiarę mamy przystęp ku tej łasce, w której stoimy i chlubimy się, w nadziei chwały synów Bożych.

W glossach do w. 1 Luter charakteryzuje nastrój całego piątego rozdziału; twierdzi, że jest to rozdział wyjątkowy, wyróżniający się wyrażaniem radości i szczęścia, ale też opisujący w klarowny sposób łaskę i miłosierdzie Boże oraz ich znaczenie dla człowieka. Przy wstępnej analizie ww. 1-2 Reformator podkreśla duchowe znaczenie pokoju, które nie przekłada się na rzeczywistość cielesną/ludzką, i łączy pokój z kiełkującą doktryną o usprawiedliwieniu. Można się tu dopatrywać osobistego doświadczenia i poszukiwań Lutra, które ostatecznie doprowadziły do tzw. przełomu reformacyjnego (datowanego na lata 1518-1520). Już kilka lat wcześniej, jak się okazuje, Luter odkrył, że odczuwanie wewnętrznego pokoju nie jest wynikiem wysiłków i ćwiczeń duchowych człowieka - „nie z uczynków, nie przez nas samych”, lecz możliwe jest dzięki zbliżeniu się do Boga, „dostępowi do Boga”. Z kolei „dostęp do Boga” jest dziełem Jezusa Chrystusa i wynikiem usprawiedliwienia z wiary: „bo bez wiary i przez Chrystusa nikt nie byłby zbawiony w owej łasce pokoju, przebaczenia grzechów i usprawiedliwienia”. Dostęp do Boga oprócz pokoju rodzi też miłość do Boga, poznanie Go oraz radość, ale wszystko to odbywa się „przez wiarę” - podkreśla Reformator.

W scholiach Luter jeszcze mocniej, na podstawie tekstów staro- i nowotestamentowych, doprecyzowuje, że pokój oznacza „spokój sumienia i zaufanie do Boga” i jest odwrotnością niepokojów wywołanych „niepewnym sumieniem i nieufnością wobec Boga". Wskazuje, że to Chrystus jest naszym pokojem. Zwraca uwagę na kolejność pojęć użytych w w. 1 oraz w Ps 85,11 i 72,11: najpierw sprawiedliwość, potem pokój; odwrócenie tej kolejności okazuje się zgubne. Człowiek szukający najpierw pokoju, a dopiero potem sprawiedliwości, nigdy pokoju nie zazna.

Sprawiedliwość i pokój połączone są przez wyrażenia „przez wiarę” oraz „przez Chrystusa” i prowadzą do „dostępu do Boga”. Oznacza to, że oba komponenty są niezbędne, by dostęp ten osiągnąć: „Dlatego musi występo- 
wać jedno i drugie, przez wiarę i przez Chrystusa, abyśmy w wierze w Chrystusa czynili i wytrzymywali wszystko, co tylko zdołamy". Ta teza staje się okazją do polemiki z tymi, którzy twierdzą, że sama wiara wystarczy, aby zbliżyć się do Boga, z tymi, którzy twierdzą, że mają już dostęp do Boga przez Chrystusa, ale bez wiary, oraz z mistykami dążącymi do zjednoczenia z Bogiem bez pośrednictwa Chrystusa ukrzyżowanego.

Ci [...] którzy przystępują do Boga przez wiarę, a nie przystępują zarazem przez Chrystusa, raczej odstępują i nikną. Ci, którzy zbyt pewni siebie przystępują do Boga przez Chrystusa, ale nie przez wiarę, jakby przez Chrystusa musieli być zbawieni i sami już nie czynią, ani też nie okazują swej wiary, [...] wcale wiary nie mają.

Mistycy, którzy „chcą słyszeć i kontemplować Słowo, które nie zostało stworzone [...]”, dążą do tego, aby być porwanymi i uniesionymi „ku Słowu niestworzonemu”, musieliby być „powołani i porwani przez Boga razem z apostołem Pawłem oraz Piotrem, Jakubem i Janem (Mt 17,1 nn.). Krótko mówiąc, owo porwanie nie jest nazwane dostępem do Boga".

Analiza w. 2 obejmuje tylko krótką glossę, w której Luter sięga do tekstu greckiego i twierdzi, że fraza ,in spe gloriae filiorum w nadziei chwały dzieci

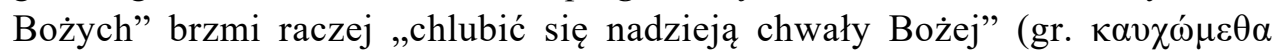

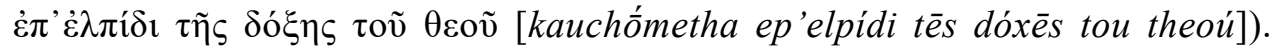
Oznacza to, że wspomniana tu chwała jest chwałą Bożą - na to przytaczany jest argument z J 5,44. Zaraz jednak Reformator powraca do tekstu łacińskiego i dodaje, że Boża chwała przysługuje wyłącznie dzieciom Bożym. Kwestii chwały nie rozwija, ale na podstawie wcześniejszych wypowiedzi, zwłaszcza analizowanego już Rz 3,23, można przypuszczać, że utożsamia ją z Bożą sprawiedliwością. Dzieci Boże z kolei to usprawiedliwieni, ci, którzy zostali tą sprawiedliwością pochodzącą od Boga przez Boga obdarowani.

Podsumowanie

W przeciwieństwie do autorów WD Luter przy analizie Ga 5,1-2 skupia się na kwestiach egzystencjalnych, nie porusza bezpośrednio kwestii eschatologicznych, na które uwagę zwracają autorzy WD. Akcentuje znaczenie „duchowego pokoju”, który można osiągnąć tylko dzięki „dostępowi do Boga” (WD posługuje się tu wyrażeniem „społeczność z Bogiem”), ale nie ocenia, że teraz „społeczność ta jest niedoskonała, a doskonała będzie dopiero w królestwie Bożym". Przeciwnie, wydaje się, że jest ona doskonała już teraz dzięki wierze i pośrednictwu Chrystusa. Te dwa komponenty: „wiara i pośrednictwo Chrystusa" są niezbędne, aby tego dostępu/społeczności doświadczyć i oba dostępne są już teraz. 


\section{ZJednoczenie Z Chrystusem, Jego Śmiercią I ZMARTwychwstaniem}

Rz 8,1-2

1 Teraz tedy nie masz żadnego potępienia tym, którzy są w Chrystusie Jezusie, którzy nie wedle ciała chodzą.

2 Albowiem zakon Ducha żywota w Chrystusie Jezusie wyzwolił mię od zakonu grzechu i śmierci.

Do Rz 8,1-2 Luter odnosi się tylko w glossach (scholia rozpoczyna się komentarzem do wiersza 3). W sposób bardzo skrótowy wyjaśnia poszczególne frazy, nawiązując cały czas i do innych fragmentów Listu do Rzymian, i do rodzącej się koncepcji usprawiedliwienia z wiary. Dlatego dwukrotnie dodaje wiarę do fraz, w których ona nie występuje, i zestawia ją z Jezusem Chrystusem, ponieważ - jak to wyjaśnił wcześniej, przy 5,1-2 - oba komponenty są niezbędne, by mówić o usprawiedliwieniu.

Pierwsza fraza: „Nie ma żadnego potępienia” jest rozpatrywana jako przeciwstawienie do $\mathrm{Rz} 7,25$, które Luter wplata w stwierdzenie o wszechobecności grzechu na świecie: „grzech występuje wszędzie, ponieważ służą zakonowi grzechu". Oznacza to, że grzech jako taki nie znika wraz z usprawiedliwieniem (brakiem potępienia), ale usprawiedliwienie dokonuje się mimo nieustającej grzeszności człowieka. Można się tu dopatrywać zalążków dialektycznej tezy simul iustus et peccator.

Przy frazie „dla tych, którzy są w Chrystusie” Luter po raz pierwszy dodaje wiarę: „dla tych, którzy przez wiarę są w Chrystusie”, co pozwala mu na odwrócenie tej relacji: ,a Chrystus w nich”. Chodzi też o zaakcentowanie, że odstąpienie od potępienia, czyli usprawiedliwienie grzesznika, odbywa się dzięki Chrystusowi i dzięki wierze. Dalszy ciąg tekstu Pawłowego traktowany jest jako opis stanu usprawiedliwienia. Usprawiedliwieni zatem, to ci, ,którzy nie postępują według ciała”. Dla Lutra nie oznacza to porzucenia ludzkiej natury, pragnień, pożądliwości, ale ich przezwyciężenie „przez ducha”, według którego postępują. To dopowiedzenie Luter wprowadza na podstawie tekstu greckiego. Pozwala mu ono uwypuklić opozycję ciało-duch, charakterystyczną dla apostoła Pawła, rozumianą nie w kategoriach antropologicznych, lecz teologicznych. Postępowanie według ciała oznaczałoby, według Lutra, postępowanie tych, którzy „będąc bez łaski, wiele zmyślają, nauczają i plotą o wielkich duchowych sprawach" ${ }^{21}$, innymi słowy: to postępowanie tych, którzy nie mają wiary. Postępowanie według ducha charakteryzuje natomiast tych, którzy z wiary (przez Chrystusa)

\footnotetext{
${ }^{21}$ M. Luter, Przedmowa do Listu do Rzymian, s. 61.
} 
zostali usprawiedliwieni. Interpretacja prawa ducha jako prawa Ducha Świętego pozwala Lutrowi wskazać źródło wiary i jej przekaziciela - Ducha Świętego. Pokłosiem wiary z kolei jest „miłość Boża rozlana w naszych sercach przez Ducha św. (Rz 5,5), który daje życie, ponieważ duch ożywia (2 Kor 3,6$)$ to, co zakon litery zabija". Przy wyjaśnieniu ostatniej frazy ponownie został podkreślony udział wiary w usprawiedliwieniu. „W Chrystusie Jezusie” przez wiarę w niego - dodaje Luter - „uwolnił mnie od zakonu grzechu i śmierci”.

Podsumowanie

Przy Lutrowej interpretacji Rz 8,1-2 najlepiej chyba widać podporządkowanie egzegezy koncepcji usprawiedliwienia z wiary przez Chrystusa. Dla Lutra staje się ona nie tylko koncepcją teologiczną, ale również zasadą hermeneutyczną. Dlatego istnieją rozbieżności między wskazaniem kluczowego znaczenia tekstu przez autorów WD i przez Lutra. Reformator nie nazywa usprawiedliwienia zjednoczeniem z Chrystusem, Jego śmiercią i zmartwychwstaniem, ale ujmuje je od strony bardzo uniwersalnej, bliskiej każdemu człowiekowi, nie tylko mistykom. Przede wszystkim usprawiedliwienie dokonuje się w wierze/przez wiarę i przez Jezusa Chrystusa - to zostało podkreślone dwa razy. Dotyczy grzeszników, którzy bez usprawiedliwienia byliby potępieni, ale dzięki usprawiedliwieniu zostali wyzwoleni spod oskarżenia prawa, przestają postępować w sposób typowy dla ciała, a zaczynają postępować w sposób charakterystyczny dla ducha. Tu można dopowiedzieć, że to postępowanie według ducha oznacza przede wszystkim dostrzeganie własnej grzeszności i potrzebę usprawiedliwienia, a nie osiąganie kolejnych etapów doskonałości duchowej. Dzięki Duchowi Świętemu usprawiedliwiony zaczyna też inaczej postrzegać prawo - nie jako drogę do sprawiedliwości, lecz jako miernik grzeszności. Paradoksalnie to właśnie sprawia, że człowiek zaczyna nie tylko spełniać uczynki prawa, ale też wypełniać prawo.

\section{KONKLUZJA}

Przeprowadzone analizy pokazały przede wszystkim, na jakich elementach poszczególnych aspektów usprawiedliwienia koncentruje się Marcin Luter. Przy egzegezie Rz 3,23-25 uwypukla rozumienie usprawiedliwienia jako daru i podaje nie tylko sposoby, ale też warunki przyjęcia tego daru. Podstawowym warunkiem jest uznanie się za grzesznika. Punktem wyjścia rozważań na temat $\mathrm{Rz}$ 5,12-21 czyni Reformator hamartiologię i rozróż- 
nienie między grzechem pierworodnym a grzechami aktualnymi. Widać tu pewne różnice $\mathrm{z}$ autorami WD w ujęciu tematu; Luter konsekwentnie akcentuje negatywne skutki grzechu i niemożność wypełnienia prawa, a tym samym bezsilność prawa w procesie usprawiedliwienia grzesznika. Pozwala mu to po raz kolejny naświetlić łaskę jako niezasłużony dar. Widać tu bardziej antropologiczne i egzystencjalne ujęcie niż w parafrazie tej perykopy w WD, gdzie autorzy zdają się akcentować przede wszystkim odpuszczenie. Komentarz Lutra do Ga 3,10-14 ma w dużej mierze charakter polemiczny, co pozwala zaprezentować dojrzałą już naukę o usprawiedliwieniu opartą na dialektyce. Luter nie musi wyprowadzać swoich wniosków teologicznych ze zorientowanej filologicznie egzegezy. Ten etap ma już za sobą. Może za to o wiele bardziej wyeksponować chrystologię i chrystocentryzm i odwoływać się do bardziej usystematyzowanej doktryny niż w wykładzie Listu do Rzymian. Różnice w rozłożeniu akcentów widać jednak najwyraźniej w komentarzach do Rz 5,1-2. Autorzy WD w parafrazie sugerują, że doskonała społeczność z Bogiem jest rzeczywistością eschatologiczną, możliwą do osiągnięcia dopiero w królestwie Bożym. Inaczej Luter, który społeczności z Bogiem nie postrzega eschatologicznie, lecz egzystencjalnie i uważa, że jest ona możliwa już teraz. Wreszcie podsumowujący punkt 11 WD passus z Rz 8,1-2, który na pierwszy rzut oka kojarzy się mistycznie, w ujęciu Lutra - dzięki chrystocentrycznej hermeneutyce zyskuje jednak wymiar antropologiczny i uniwersalny.

\section{BIBLIOGRAFIA}

BARTH Hans-Martin: Die Theologie Martin Luthers. Eine kritische Würdigung, Gütersloh: Gütersloher Verlag-Haus 2009.

Betz Hans Dieter: Galatians. Hermeneia: A Critical \& Historical Commentary on the Bible, Philadelphia: Fortress Press 1979.

Biblia w przekladzie księdza Jakuba Wujka z 1599 roku. Transkrypcja typu „B” oryginalnego tekstu z XVI w. i wstępy Janusz Frankowski. Prymasowska Seria Biblijna, Warszawa: Vocatio 2013.

Biblia Święta tho jest Księgi Starego y Nowego Zakonu wlasnie z Zydowskiego/Greckiego/y Łaćińskiego nowo na Polski ięzyk z pilnośćia y wiernie wyłożone [tzw. Biblia brzeska], Brześć: [s.d.] 1563.

LuTER Marcin: Artykuty szmalkaldzkie, przeł. Wiktor Niemczyk, w: Księgi wyznaniowe Kościoła luterańskiego, Bielsko-Biała: Wydawnictwo Augustana 2011.

Luter Marcin: Przedmowa do Listu św. Pawła do Rzymian, w: Tenże, Przedmowy do ksiag biblijnych, przeł. Jerzy Krzyszpień, Warszawa: Ogród Ksiąg 1992. 
Luter Marcin: Przedmowa do Starego Testamentu, w: Tenże, Przedmowy do ksiag biblijnych, przeł. Jerzy Krzyszpień, Warszawa: Ogród Ksiąg 1992.

Luter Marcin: Wykład Listu do Rzymian, przeł. Iwona Slawik, Dzięgielów: Wydawnictwo Warto. Centrum Misji i Ewangelizacji Kościoła Ewangelicko-Augsburskiego 2010.

LUTHER Martin: Commentary on the epistle to the Galatians, https://www.gutenberg.org/ files/1549/1549-h/1549-h.htm, dostęp: 10.10.2019.

LuTHER Martin: Lectures on Romans, edited and translated by Wilhelm Pauck, Louisville: Westminster John Knox Press 1961.

Obermann Heiko Augustinus: Marcin Luter człowiek między Bogiem a diabłem, przeł. Elżbieta Adamiak, Gdańsk: Wydawnictwo Marabut 1996.

Whitford David M.: Luther. A Guide for the Perplexed, London-New Delhi-New YorkSidney: T \& T Clark International 2011

Wspólna deklaracja $w$ sprawie nauki o usprawiedliwieniu, https://ekumenia.pl/czytelnia/ doku menty-ekumeniczne/wspolna-deklaracja-w-sprawie-nauki-o-usprawiedliwieniu/. Dostęp: 8.11. 2019.

\section{„ŁASKĄ... PRZEZ WIARE” \\ - LUTRA KONCEPCJA USPRAWIEDLIWIENIA GRZESZNIKA PERSPEKTYWA EGZEGETYCZNO-HERMENEUTYCZNA}

Streszczenie

W artykule przeanalizowano kwestię usprawiedliwienia przez wiarę z perspektywy Wspólnej Deklaracji (WD) oraz na bazie dwóch komentarzy Marcina Lutra: Wykładu Listu do Rzymian (1516) oraz Komentarza do Listu do Galatów (1535). Ponieważ komentarze pochodzą z różnych okresów twórczości Lutra, dobrze obrazują rozwój koncepcji usprawiedliwienia przez wiarę. Omówione zostały te aspekty usprawiedliwienia, które jako kluczowe wymienia Wspólna Deklaracja w punkcie 11: usprawiedliwienie jako odpuszczenie grzechów, wyzwolenie z mocy grzechu i śmierci, wyzwolenie od przekleństwa zakonu, jako społeczność z Bogiem i jako zjednoczenie z Chrystusem, Jego śmiercią i zmartwychwstaniem. Każdy z omawianych aspektów kończy się podsumowaniem ukazującym podobieństwa i różnice między Lutrowym ujęciem usprawiedliwienia a interpretacją nauki o usprawiedliwieniu w WD.

Słowa kluczowe: usprawiedliwienie; wiara; prawo; Ewangelia; łaska; Marcin Luter; Komentarz do Listu do Galatów; Wyktad Listu do Rzymian; Wspólna Deklaracja w sprawie nauki o usprawiedliwieniu. 